\title{
Justice for Women!
}

\author{
Percy B. Lehning1
}

\section{A RESPONSE TO EDWARD E. SAMPSON}

The main points of Sampson's critique against Lehning (1990) are summarized by Sampson in the following way:

By failing to deal with the postmodern challenge to the Enlightenment-liberalist conception of neutrality and by thoroughly ignoring the feminist understanding in which neutrality actually conceals a masculinist bias, Lehning's analysis is seriously undermined with respect to its possibility for understanding, let alone for accomplishing justice. (Sampson, 1994, Abstract)

My response is based on these points of critique.

\section{Feminism and Postmodernism}

The precise character of the relationship between feminist theory and postmodernism is a subject for debate. Postmodernism may have a great deal to offer to feminism but "almost all [feminist theorists] also agree that there are some serious problems with the relationship between the two" (Hirschmann, 1992, p. 300).

Any number of anthologies on this subject support this claim (see, for instance, Benhabib and Cornell, 1987). The question is: Can feminism become postmodernist and claim to develop a theory in the interest of women's emancipation? Benhabib remarks, after an analysis of Flax's Thinking Fragments (1990) [a book used by Sampson to support his own claims]: "The postmodern position(s) thought through to their conclusions may eliminate not only the specificity of feminist theory but place in question the very emancipatory ideals of the women's movement altogether"

${ }^{1}$ Department of Public Administration, Erasmus University, Postbox 1738, 3000 DR Rotterdam, The Netherlands. 
(Benhabib, 1992, p. 213). Hartsock (1990) even remarks that "postmodernism represents a dangerous approach for any marginalized group to adopt" (p. 16). For Hirschmann (1992) there cannot be a feminist postmodernism, only a postmodern feminism that can borrow from certain insights of postmodern theories. It can help feminist political theorists to develop their arguments on sexual difference and the need to attend to context and particularity (p. 318).

In conclusion, notwithstanding these different opinions, there is evidently no doubt in Sampson's mind about the character the relationship between feminism and postmodernism should have. In that regard it is striking to note that he makes no reference whatsoever to this debate between feminist theorists on this question.

\section{Liberalism and Difference}

The feminist-difference issue is, according to Sampson, a problem in my work. On the problem of representing differences, Gould (1993) has written:

It has become a commonplace in political theory to criticize liberalism for its abstract universality and abstract individualism, in which differences other than those of political opinion are ignored or overridden and assigned to the private sphere.

.... But the neglect of difference in liberalism should not be exaggerated. (p. 1)

One should add that it has, nowadays, become fashionable to write of earlier traditions as insufficiently attentive to difference and too much preoccupied with ideals of equality that require us to be, or become, the same. As Phillips (1993) has summarized:

\footnotetext{
Feminist writing in the 1980s often regarded their own previous incarnations in this light, and argued that an exclusive emphasis on sexual equality was requiring women to replicate male models of democracy or employment or justice or rights. Liberalism turned out to a favourite target of attack, and both feminist and socialist have regarded it as a tradition that erases difference-not in reality, of course, but in thought. Liberal political theory is said to assert an essential sameness of condition that overrides the differences between us, appealing to a natural equality in rights or the possession of reason that will stop these differences from counting. (p. 2)
}

It is possible, however, with only a minor change of emphasis to view liberalism as founded on the very pertinence of difference as Phillips herself has noted.

Instead of describing it as overriding difference, we might equally well see liberalism as pursuing an essential sameness of condition in order to underwrite the very real differences between us. . . [Liberalism] is driven precisely by what it seems as the power and the tensions of difference. Notions of diversity and difference then ap- 
pear central to liberalism from its inception and to liberal democracy throughout its formation. (p. 3)

I, of course, do not claim that these ideas have been realized in practice. The point is that there is, contrary to Sampsons's suggestions, nothing "phallocentric" in this liberal democratic framework. On the contrary, I agree with Mendus (1992) who in an essay on feminism and democracy has suggested that difference is the rationale for democracy. To make this point clear it is necessary to make a distinction between two levels of democratic interest: the principle of inclusion and the principle of equality. At the first level, difference should be ignored. Differences of class, race, and gender should not matter when deciding on citizenship. At the second level these differences should be recognized, but not eliminated.

For whereas traditional democratic theory tends to construe difference as an obstacle to the attainment of a truly democratic state, feminist theory should alert us to the possibility that difference is rather what necessitates the pursuit of democracy. (Mendus, 1992, p. 216)

In conclusion, Sampson in much too eager to reach the conclusion that liberal political theory and liberal democracy are unable to deal in an adequate way with differences. $\mathrm{He}$, in fact, would have a hard time convincingly arguing so.

\section{Justice and Difference}

The feminist-difference issue that is claimed to be a problem in my work also-according to Sampson-permeates my ideas on justice. Is this indeed the case?

In regard to "diversity and democracy" and the problem of representing differences, Gould (1993) has remarked that an alternative theoretical framework in which differences would be adequately recognized and effectively taken into account in the public domain, remains undeveloped and problematic (p. 2) Taking differences seriously in the social and political domain means taking rights seriously. It involves a conception of rights and justice that are not difference-blind in its principles of equal rights mandating a sameness of treatment, but it involves principles that build a recognition of difference and the protection of the rights of difference into its basic conception.

Rawls's (1993) theory is an example of a theory that tries to do just this, as I argued in Lehning (1990). This theory acknowledges difference as a concern for justice. Differentiation is built into the basic requirement of just treatment. Justice as equal freedom should not entail only the nega- 
tive liberties and equal political rights but also equal rights to the condition of differentiated self-development, positive freedom. ${ }^{2}$

The critique that I developed with regard to Rawls's conception of primary goods had to do with the fact that justice requires not the same conditions for each other, but equivalent conditions determined by basic capabilities. Because justice entails a recognition and consideration of relevant differences, I argued that we should replace Rawls's conception of primary goods by Sen's conception of basic capabilities. We would then be more able to capture the realization of positive freedom and differences would be better recognized.

In conclusion, Sampson has not shown at all that the theory of justice that is developed in Lehning (1990) is indifferent to differences; they are not overridden or stopped from counting.

\title{
Capabilities and Difference
}

Sampson (1994) is so obsessed with trying to make his point about the feminist challenge to all conceptions of neutrality, that his critique takes a strange turn, not to say a malign one, when we come to the point of "basic capabilities." He claims he first became aware that the feminist-difference issue was a problem in my work when I

\begin{abstract}
listed the fundamental kinds of diversity that mark the human being, including differences based on metabolic rates, physical conditions, longevity, health, body size, temperament, and so forth, but excluding (by omission) sex. Lehning uses these differences to illustrate why state neutrality is so important to ensure just allocations (p. 150) .... Now, while Lehning's list accurately describes some of the various ways in which people differ from one another; and while Lehning is correct to note that these are the very differences that can enter significantly into just allocations, by omitting sexual differences from the list, he avoids confronting the feminist challenge to all conceptions of neutrality and so can be lulled into sustaining a belief in state neutrality [emphasis added]. (p. 150)
\end{abstract}

This is really an absurd point of critique. The implication is that $\mathrm{I}$, on purpose, omitted sexual differences from the list to avoid the feminist challenge. Let us get the record straight.

I have argued in Lehning (1990) that Sen criticizes Rawls's approach of primary goods because Rawls does not cope in an effective way with the problem of the fundamental diversity of human beings. The availability of an adequate range of options derives its value from the contribution it

\footnotetext{
${ }^{2}$ See also Gould (1988). She proposes principles of justice that builds a recognition of difference and the protection of the rights of difference into its basic conception. She recognizes that Rawls also incorporates an acknowledgment of difference as a concern of justice, e.g., in his difference principle. She notes, however, that this acknowledgment is not as comprehensive as the one she herself proposes.
} 
makes to the equal freedom of each person to lead a good life of his own choice. As I wrote: "In this perspective the recognition of the fundamental diversity of human beings has very deep consequences" (p. 307). I went on quoting Sen (1988) which I shall do again:

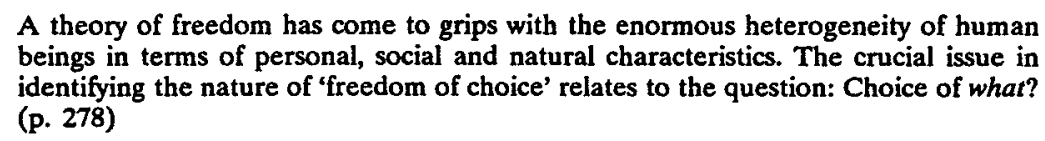

A theory of freedom has come to grips with the enormous heterogeneity of human beings in terms of personal, social and natural characteristics. The crucial issue in identifying the nature of 'freedom of choice' relates to the question: Choice of what? (p. 278)

Anyone who wants to argue that sexual differences are not included in this conception of freedom and choice, places himself outside the range of a reasonable debate on the implications of the idea of basic capabilities. (And, for that matter, on the implications of political neutrality.) But my saying so may not be convincing enough. I quote Sen (1990) himself when he discusses his conception of basic capabilities: "Variations related to sex, age, genetic endowments, and many other features give us unequal powers to build freedom in our lives even when we have the same bundle of goods" (p. 121).

Evidently it is necessary to point out to some that, in fact, in Sen's approach, where abilities to take action, and not resources, are the primary goods, we can take account of the fact that individuals have varying needs for resources, in accordance with their social and physical circumstances, the special obstacles they face, and so forth. It is from that perspective that Sen discusses, for instance, the empirical issues involved in the variable conversions of primary goods (and resources) into capabilities (and freedom) with respect to Indian women.

Okin (1989) has argued convincingly in Justice, Gender, and the Family that, for a number of reasons, the division of labor that prevails between the sexes is a matter of social injustice. It often leads to economic, psychological, or even physical vulnerability of women and children. It contributes to women's inequality of opportunity and actual inequality of power and influence in society at large. I must admit that I really cannot see that only a postmodern feminist point of view can lead to this insight. Even less is it clear to me why the concept of "basic capabilities" would not be a way to deal with these problems. It is, then, from this perspective, the perspective of "functioning and capability" that one should understand Sen's and, one should add, Nussbaum's development ethic. (For an insightful analysis of Nussbaum's and Sen's development ethic, see Crocker, 1992.) It is from this perspective that the contributions to, for instance Human Capabilities: Women, Men and Equality (Nussbaum and Glover, 1993) are written. (See also Nussbaum, 1992; Nussbaum and Sen, 1993.)

In conclusion, there is no reason whatsoever not to include sexual differences in the list of ways in which people differ, and certainly not from 
the perspective of justice that has been defended in Lehning (1990). ${ }^{3}$ Contrary to what Sampson suggests, these differences where not at all omitted in Lehning (1990) "to avoid the feminist challenge."

\section{Impartiality and Difference}

Sampson may claim that I have missed the core of his critique. He may want to argue that it is not directed against the conception of basic capabilities as such, or against justice as such, but its target is the conception of neutrality I use. That conception "actually conceals a masculinist bias," and: "the disturbing feature of the Enlightenment-liberalist project, Lehning's included, [is] its clearly masculinist bias hidden under the guise of neutrality" (Sampson, p.148). And

Much of the feminist critique of neutrality is built upon its theory of sexual differences. The feminist theory of difference argues that state neutrality is not simply and idle myth surviving from the Enlightenment, but serves to conceal the partiality that inheres in the very belief in impartiality. (p. 149)

Let us first recapitulate. I wrote that the

central argument favoring the liberal notion of neutrality is that it is necessary if one acknowledges that there exist a variety of conceptions of the good life. There are many ways in which a fulfilled life can be lived, without any perceptible hierarchy among them. (Lehning, 1990, p. 188)

And:

The stress upon neutrality and equal respect, which denies the state any right to implement any specific conception of the good life, emphasizes the equal freedom that all persons should have to pursue their own conception of the good life. (p. 189)

The public role of a neutrally recognized political conception of justice is to specify a point of view from which all citizens can examine before one another whether or not their political institutions are just. It has been my contention that Rawls's conception of justice is, in fact, an example of such a political conception of justice. This contention is based on the idea that the way Rawls has formulated his conception of justice is founded on the ideal of impartial moral reason.

Now for instance Young (1990) has argued (with reference to Rawls's theory) that the ideal of impartiality is an impossibility, and that it denies difference. (I follow here Young, 1990. On this point Sampson's argument is essentially the same as that of Young.) In fact, she claims that the ideal

${ }^{3}$ This of course does not imply that the conception of basic capabilities, as an alternative to Rawls's primary goods is immune against criticism. See for a reaction on Sen's ideas, Rawls (1993, pp. 182-186). See also Daniels (1990). 
of impartiality in moral theory expresses a logic of identity that seeks to reduce differences to unity ( $\mathrm{p}$. 97). This conception of moral reason assumes that

in order for the agent to escape egoism, and attain objectivity, he or she must adopt a universal point of view that is the same for all rational agents. The ideal of impartiality is the result of this search for a universal, objective "moral point of view." (pp. 99-100)

In sum, Young's argument is that impartial reason aims to adopt "a point of view from nowhere," and therefore denies difference. I suggest, however, that impartial reason does not take a point of view from nowhere but, on the contrary, a perspective from which all points of view are taken seriously, with the purpose of taking into account all differences.

It is, of course, the function of Rawls's well-known device of the "Original Position" to do just this. The "veil of ignorance" guarantees impartiality when principles are formulated that should regulate the basic structure of society. Hypothetical people in selecting principles of justice are deprived of knowledge of their own particular place in society, their class, occupation, sex, and so forth, and therefore have to consider the wellbeing of everyone, from the best-off to the worst-off, on the hypothesis that they could be any one of them.

In conclusion, contrary to what Young (1990) and Sampson (1994) claim, impartiality does not do away with difference. I agree with Nussbaum (1992, p. 45) and Okin (1989, p. 101) that the exercise of impartial moral imagination is enormously valuable for understanding the lives of, for instance, women, and that Rawls's theory of justice can be a tool for feminist criticism.

\section{Neutrality and Difference}

Sampson claims that one of the reasons $I$ have made a choice in favor of neutrality is that "If there is no neutral place to stand, we worry that there will be no way to choose among competing views, no fair way to allocate resources" (p. 147). And he continues to remark that

The choices are not between neutrality or death, chaos or madness, but rather between neutrality and the need for people to operate together, in full knowledge of their interests and situatedness, to probe and to negotiate the terms by which they will live together imperfectly in this world of their differences. (pp. 147-148)

I, for my part, certainly have not claimed that the choice is death or neutrality. But there is more to it. The choice is not between, on the one hand, neutrality and, on the other, the need for people to cooperate together in full knowledge of their interests and situatedness. The question is how to 
achieve this cooperation. The upshot of my article has been to show that neutrality is a plausible basis for this "negotiation" if it is to be on the basis of reason rather than superior force. The best we can say of Sampson's critique is that he has misinterpreted the ideal of "neutrality" and "the neutral state" as developed in Lehning (1990) or has been misled by the term neutrality.

Let us try, once again, to make clear the argument on which the idea of neutrality has been based. The starting point for using the concept neutrality was Rawls's idea of political liberalism. The central aim favoring the liberal notion of neutrality is that it is necessary if one acknowledges that there exists a variety of conceptions of the good life. In response to this variety, to pluralism and reasonable disagreement political liberalism formulates the principle that the state should be neutral with respect to this diversity of conceptions of the good life.

Neutrality can be defined in quite different ways. As Rawls (1993) has noted: "[S]ome forms of liberalism are neutral in the sense that they use no ideas of the good at all except ones that are purely instrumental (neutral means, as it were).... [J]ustice as fairness is not neutral in this way ...." (p. 191, note 22). The Rawlsian principles of justice are substantive. The principles express far more then procedural values, and so do its political conceptions of society and person, which are represented in the original position. Justice as fairness, then, is not procedurally neutral.

A different way of defining neutrality is neutrality of aim. In Lehning (1990) it has been used in this way. There neutrality has been defined in terms of the aim of basic institutions and public policy with respect to comprehensive doctrines and their associated conceptions of the good. Neutrality of aim (as opposed to neutrality of procedure) "means that those institutions of society and policies are neutral in the sense that they can be endorsed by citizens generally as within the scope of a public conception" (Rawls, 1993, p. 192). This neutrality of aim is not to be confused with neutrality of effects or influences. Following Rawls (1993) it should be noted that

$$
\begin{aligned}
& \text { it is surely impossible for the basic structure of a just constitutional regime not to } \\
& \text { have important effects and influences as to which comprehensive doctrines endure } \\
& \text { and gain adherents over time; and it is futile to try to counteract these effects and } \\
& \text { influences, or even to ascertain for political purposes how deep and pervasive they } \\
& \text { are. We must accept the facts of commonsense political sociology. (p. 193) }
\end{aligned}
$$

Recapitulating, procedural neutrality should be distinguished from neutrality of aim; the latter should not be confused with neutrality of effect or influence. Justice as fairness hopes to satisfy, as Rawls mentions, neutrality of aim in the sense that basic institutions and public policy are not to be designed to favor any particular comprehensive doctrine. Political 
liberalism abandons, however, as impracticable neutrality of effect or influence. ${ }^{4}$ [One could add that recently Rawls (1993, p. 194) noted that the term neutrality is unfortunate because some of its connotations are highly misleading, others suggest altogether impracticable principles such as neutrality of effect, a idea strongly suggested by the term itself. It is a reason for avoiding the term.]

A clear example of misunderstanding the way the concept neutrality is used, is evident from the following remarks of Sampson (1994)

Tax laws, of course, do deal directly with allocation decisions and should thereby provide us (and Lehning) with a prime case of state neutrality. And yet, as we all know, there is no way to devise tax legislation that does not advantage some and disadvantage others. Neutrality here . . . is a myth that serves some interests over others. (p. 149)

Sampson is quite right in stating that tax laws deal with allocation [or, as I rather would say, with (re-) distribution] decisions. The implication of his remark is that, by making such decisions state neutrality is a mirage. Tax legislation always advantages some and disadvantages others.

I will not argue that this is not what, in fact, tax law does. The question is if this is a proof of the myth of the conception of state neutrality as that conception has been used in my article. I would say it is not. Let me elaborate. The point is not at all whether tax legislation advantages some and disadvantage others. In that sense Sampson's feminist example is beside the point, since it actually appeals to premises about equal treatment that a neutralist would accept. The point is rather to design tax laws that advantage and disadvantage persons in a way that is in line with principles of justice. This is what Rawls's "difference principle" is supposed to do. It is a principle that is especially relevant for the design of tax laws. As part of the Rawlsian conception of political liberalism the difference principle is part of the basic institutions of society and policies. This principle should also be endorsed by each citizen because it is neutral with regard to conceptions of the good life that citizens are persuing.

This does not mean, however, that the application of the difference principle works out the same for everybody. The purpose of the difference principle is to guarantee that inequalities in, for instance, income work out to the greatest benefit of the least advantaged members of society. It may be the case that the difference principle requires a design of tax laws which

${ }^{4}$ It should be emphasized that neutrality in aim does not mean that political liberalism may not affirm the superiority of certain political virtues. Justice as fairness thus includes the virtues of fair social cooperation such as the virtues of civility and tolerance, of reasonableness and the sense of fairness. See Rawls (1993, p. 194).

${ }^{5}$ See also Young (1990): "The idea of neutrality that stands above the particular interests and conflicts of civil society is, however, a myth" (p. 114). 
have as effect that some have to pay more tax and some have to pay less because the aim is reaching a situation of equal concern and respect for everybody or, to formulate it in another way, a situation of equal basic capabilities. The burden of taxation is to be justly shared, but as with the right to equal protection which may require an unequal distribution of police over different neighborhoods, a just tax legislation may require that some have to pay more than others.

In conclusion, from my part it would be rather preposterous to drop right now the term neutrality as a rebuttal to Sampson's critique. The important point to note is, however, that the use of the term neutrality, which I have tried to make more clear above, should not have been interpreted to mean indifference to differences, as Sampson claims. On the contrary, the liberal notion of neutrality should guarantee that differences will be taken care of in such a way that each citizen, male or female, hetero- or homosexual, will be treated with equal concern and respect.

\section{Feminism and Justice}

Sampson is of the opinion that the kind of constitutive sense of personhood that Sandel (1982) recommended, and that according to Sampson $(1994$, p. 153) is the centerpiece of the postmodern feminist analyses, better fits the understanding of justice then the one I have given. I am not so sure, for several reasons. Let me mention just one. One aspect of Sandel's arguments, to insist that families be internally just, is misguided. The family is according to him, "beyond justice" and not an appropriate topic for a theory of justice. Okin (1989, Chap. 2) questioned this position, especially when we notice whose interest the ideas of love beyond justice has frequently served. Sandels's theory is in that sense not gender-neutral at all. At the same time as ignoring families, theories like Sandel's assume, as Okin has noted, that meals will be cooked, houses cleaned, etc., in short the reproduction of people will continue.

It is rather a surprise to discover at the end of Sampson's criticism of my article, that he recommends to turn to a theorist for whom the family is beyond justice, but who nevertheless envisions-according to Sampson-the postmodern feminist view of justice.

In conclusion, I have not been very impressed by Sampson's critique. The question is whether there is a coherent basis for social institutions to be constructed from the so-called feminist-postmodernist line. If so, it does not emerge here (and I very much doubt if it exists). All in all, Sampson's antiliberal challenge misfires. This does not mean that all is well with liberalism. On the contrary. That is, however, another story. 


\section{REFERENCES}

Benhabib, S. (1992). Situating the Self; Gender, Community and Postmodernism in Contemporary Ethics, Polity Press, Oxford.

Benhabib, S. and Cornell, D. (eds.). (1987). Feminism as Critique, Polity Press, Oxford.

Crocker, D. A. (1992). Functioning and capability; The foundation of Sen's and Nussbaum's development ethic. Polit. Theory 20: 584-612.

Daniels, N. (1990). Equality of what: Welfare, resources, or capabilities? Philos. Phenomenol. Res. 1: 273-296.

Flax, J. (1990). Thinking Fragments, University of California Press, Berkeley.

Gould, C. C. (1988). Rethinking Democracy; Freedom and Social Cooperation in Politics, Economy, and Society, Cambridge University Press: Cambridge, U.K.

Gould, C. C. (1993). Diversity and democracy: Representing differences. Paper written for "Democracy and Difference." Conference for the Study of Political Thought, Yale University, New Haven, CT, April 16-18.

Hartsock, N. (1992). Foucault on power: A theory for women? In Nicholson, L. (ed.), Feminism/Postmodernism, Routledge, New York.

Hirschmann, N. J. (1992). Rethinking Obligation; A Feminist Method for Political Theory, Cornell University Press, Ithaca, NY.

Lehning, P. B. (1990). Liberalism and capabilities: Theories of justice and the neutral state. Soc. Justice Res. 4: 187-213.

Mendus, S. (1992). Losing the faith. Feminism and democracy. In Dunn, J. (ed.), Democracy; The Unfinished Joumey 508 BC to AD 1993, Oxford University Press, Oxford, pp. 207-219.

Nussbaum, M. (1992). Justice for women! The New York Review of Books, October 8, pp. 43-48.

Nussbaum, M., and Sen, A. (eds.). (1993). Quality of Life, Clarendon Press, Oxford.

Nussbaum, M., and Glover, J. (eds.). (1993). Human Capabilities: Woman, Men and Equality, Clarendon Press, Oxford.

Okin, S. M. (1989). Justice, Gender, and the Family, Basic Books, New York.

Phillips, A. (1993). Dealing with difference; From a politics of ideas to a politics of presence. Paper written for "Democracy and Difference," Conference for the Study of Political Thought, Yale University, New Haven, CT, April 16-18.

Rawls, J. (1993). Political Liberalism, Columbia University Press, New York.

Sampson, E. E. (1994). Justice and the neutral state. A postmodern feminist critique of Lehning's account of justice. Soc. Justice Res. 7: 145-154.

Sandel, M. (1982). Liberalism and the Limits of Justice, Cambridge University Press, Cambridge, U.K.

Sen, A. (1988). Freedom of choice. Eur. Econ. Rev. 32: 269-294.

Sen, A. (1990). Justice: Means versus freedom. Philos. Public Affairs 19: 111-121.

Young, I. M. (1990). Justice and the Politics of Difference, Princeton University Press, Princeton, NJ. 